\title{
Remembering: a narrative with different characters Lesley Carroll
}

Reflection begins with the presence of difference and otherness in experience. Difference provokes thought. ${ }^{1}$

\begin{abstract}
I recently attended a conference at which a speaker from Romania posed this question:
\end{abstract}

How do we transmit the memory of atrocities, victimhood dictatorship, to people who have already heard that story, only with different characters?

In this article I take remembering in Northern Ireland as a story with different characters. A shared narrative to transmit the memory of what happened over thirty years of Northern Irelands Troubles remains to be told by and for the whole society. The purpose of a shared narrative is to contribute to a number of mechanisms that direct society to a future in which what happened in the past will never happen again. By a shared narrative I mean one that reflects the different characters and experiences, from different local experiences to different individual and community experiences. An agreed narrative is not possible at this time and perhaps that should never be the ambition for it would obscure the many characters within the one narrative. The kind of narrative that is shared may be defined as a 'composite' narrative that tells about individuals within the broader context of what was happening across Northern Ireland. It is important that remembering is understood to be narrative and not event, composite and not obscuring the characters involved. I will reflect on visits to Yad Vashem and the Kigali Memorial Centre as place where narrative was evoked about how to remember well for a better future where there has been conflict. I will share some of that challenges to remembering together in Northern Ireland and I will look to the Passover Seder and Lord's Supper for wisdom. I will conclude with some challenges to remembering as a contributor to peacemaking but without betrayal.

\section{Biography}

The concern about how we remember together is one close to my heart. I have served on a government appointed commission to consider how to deal with Northern Ireland's troubled past. ${ }^{2}$ I have worked with victims and survivors from all political backgrounds for all of my time as a minister and most recently as an associate member of the Northern Ireland Forum for Victims and Survivors. ${ }^{3}$ The remembered past of which I write is my past. The recent

\footnotetext{
${ }^{1}$ Polling, J. N. (1991). The Abuse of Power: A Theological Problem. Nashville: Abingdon Press), 7.

${ }^{2}$ I was a member of The Consultative Group on Dealing with the Past which reported to government in January 2009.

${ }^{3}$ March 2012 - March 2014.
} 
Troubles in Northern Ireland are considered to have begun in 1969. I was seven years old. I vividly remember soldiers with guns, police checkpoints, paramilitary activity near my home, tear gas, rubber bullets, the sound of explosions, the dust and devastation after bombs have gone off, and the faces of some of those who were killed. Fear and anxiety pervaded our lives as young people when we should have been carefree. I cannot forget.

\section{Remembering or forgetting}

Remembering is a duty to both the dead and the living. The ties of human relationships make it impossible to forget loved ones. Individuals should remember their loved ones. Postconflict societies have reservoirs of painful memories and raw history. Forgetting is not an option if the conflicts, troubles and violence of the past are to be resisted. Remembering is about making a better future as well as calling to mind the past and honouring those who have died. In Northern Ireland we call this, 'dealing with the past.' It is in the context of dealing with the past that remembering takes on a critical character if the past is not to be repeated. In this sense remembering has a whole society significance.

The signing of the Belfast Good Friday Agreement in 1998 marked an interruption in our history after some thirty years of violence and unrest. Rumbles of the past can still be felt today. We are not the society we used to be but the old hatreds remain, for some more than others, and from time to time violence breaks through. We are not in a place to forget for the past is still with us but we have yet to find a way of remembering as a whole society.

Forgetting is not an option, or, as some describe it, 'drawing a line under the past.' Every week new issues from the past emerge through the criminal justice system - incomplete inquests from as far back as the 1970s, new calls for inquiries and the repetition of old calls for inquiries, new evidence and arrests. Three thousand cases remain unsolved. However much we might want to forget the past, the past will not let us forget. How we remember is, therefore, critical to completing the peace. I will consider challenges to remembering in Northern Ireland society and look to the Judeo-Christian tradition for inspiration and wisdom.

\section{Remembering as narrative and not event}

From time immemorial human beings have made monuments to mark significant moments or times of change. These monuments bear witness to chosen, interruptive historical experiences and construct the significant past experiences that inform group identity. As the character Zenia, in Margaret Atwood's book The Robber Bride, explains, these are times after which things will never be the same again:

History is a construct, she tells her students. Any point of entry is possible, all choices are arbitrary. Still, there are definitive moments, moments we use as references, because they break our sense of continuity, they change the direction of time. We 
can look at these events and we can say that "after them things will never be the same again. They provide beginnings for us, and endings too." 4

In the Judeo-Christian tradition the Genesis accounts of Abraham's journey provide history to God's people that is marked by physical constructions or memorials. Abraham began his journey into the unknown, setting out with God ahead of him and leaving behind all that was familiar to him. He arrived in Canaan where the Lord appeared to him. It was an event worth marking and so Abraham built an altar. ${ }^{5}$ This was the first of four altars built at stages on his journey. The background noise of stone on stone, built with sweat and strength, produced markers at significant places along the way. They were places from which there was no return. These altars may be understood as markers and reminders of God's faithfulness as Abraham journeyed from the old country to the new land. They were visible, invoking remembrance of God who journeyed with Abraham.

The static nature of these altars suggests a static nature to remembering. They provided a snapshot into a moment in history, who the characters in that history were and what they were marking. It is what they marked that was important. Static memorials evoke thought and begin a narrative in the minds of those who gather as they call to mind the narrative of past events, the life-changing impact of events and the narrative of their own lives in relation to the narrative of the past. Remembering requires event but remembering is itself narrative. As such, remembering is dynamic and continues to shape and change lives.

\section{Remembering at Yad Vashem}

Yad Vashem, the Jerusalem memorial to those lost in the Shoah, is a carefully designed and crafted structure. The name Yad Vashem is taken from Isaiah $56,{ }^{6}$ chosen to indicate that this is, 'a place specifically to memorialize. ${ }^{7}$ It has been many years since I visited Yad Vashem but the imprinted memory of that visit remains. It is impossible to forget the children's memorial with the little shoes, countless pairs of shoes standing still in soft light. Each pair of shoes tells the story of a life cut short, shoes never worn out with walking. The onlooker realizes, as narrative begins, that with each lost life we have lost the laughter and the skills of children who would have grown up to be parents and scientists and writers and teachers and philosophers and chefs and watchmakers. We are depleted by their loss. Small shoes. Standing still. Static in their testimony to lost lives but evoking narrative, much of it a narrative of what might have been and what should not have been.

\footnotetext{
${ }^{4}$ Atwood, M. (1993). The Robber Bride. London: QPD, 4.

${ }^{5}$ Genesis 12:7 "...but the Lord appeared to Abram and promised, "I will give this land to your family forever." Abram then built an altar there for the Lord."

${ }^{6}$ Isaiah 56:4-5. "To them, I, the Lord, say: Respect the Sabbath, obey me completely, and keep our agreement. Then I will set up monuments in my temple with your names written on them. This will be much better than having children, because these monuments will stand there forever.

${ }^{7}$ Rabbi David Kimchi, http://en.wikipedia.org/wiki/Yad_Vashem, accessed 22.07.2014.
} 
Vashem is a memorial to an event after which things would never be the same again. Remembering summons narrative that insists commitment is made to endeavour that it never happens again. The purpose of Yad Vashem is described in a mission statement that emphasizes the importance of remembering:

As the Jewish people's living memory to the Holocaust, Yad Vashem safeguards the memory of the past and imparts its meaning to future generations. ${ }^{8}$

Remembering forms the narrative that shapes life, moving from event to narrative, from snapshot of history to hope for the future. The values drawn from the narrative make the difference. Remembering is never simply about the past. It is an opportunity to choose values, hopes and dreams in the here and now to give form and direction for those who remember as they live in their time and place. As the memory of the past imparts meaning to new generations so the remembering narrative beseeches a lifestyle and values that safeguard the future.

Remembering is painful, full of sorrow. What is remembered can be obscene as the concentration camps were obscene. The empty shoes at Yad Vashem evoke a pain impossible to articulate. It should not have happened. It should never happen again. 'Shoed' by the narrative of what happened onlookers choose how to walk out of Yad Vashem. They can walk out with vengeance or with a commitment that such dehumanizing behavior is resisted at all costs.

Woven through the narrative of hope for a better future there is a narrative of outrage that so many lives were lost. For what? The loss, the despair and hardship experienced by those who endured the camps, raise outrage at blind eyes turned and justifying narratives constructed. And then ... outrage collapses as the weight of loss bears down. The onlooker realizes not that this could happen again but that it has.

Remembering opens up many narratives: The narrative of mourning and loss, attending to the dead; the narrative of those forever scarred by experience. Those who continue to suffer must be given time and resources to heal, as best they can. If the loss, the past and the remembering are not to consume then some meaning needs to be made of horrific events and often that meaning is found in the struggle against such things ever happening again. When past and future collide new narrative begins in the hope that the future will be different.

\section{Remembering where past and future meet}

In August 2013 I boarded an aircraft with friends and colleagues to make the journey to Rwanda. I had done considerable preparatory reading in an attempt to imagine what I might

\footnotetext{
${ }^{8}$ http://www.yadvashem.org/yv/en/about/, accessed 22.07.2014.
} 
feel in a country where, in 1994, upwards of one million people died. The Rwandan genocide took place over only one hundred days.

Our first day began with a visit to the Kigali Memorial Centre. It echoed with so much of what I had felt so many years before at Yad Vashem. At the Centre there is a plaque, one among many. It reads:

So when you said never again after the holocaust was that meant for some people and not others?

There is a children's garden. No plaques. No names. It resonates with the loss of future and hope. There are walls of names around the Memorial Centre. I was struck by the repetition of family names telling a story of whole families lost. The narrative suggested the Memorial Centre is of the construction of ethnicity by colonial powers, an important contributor to the genocide in which ethnic Hutus turned on ethnic Tutsis. The flow of three memorial gardens symbolizes a narrative that moves from unity to division and then to reconciliation.

Scholarly discussion considers whether Rwanda has adopted a strategy of, 'chosen amnesia, ${ }^{\prime 9}$ in order to survive the wake of the genocide. This article is not the place to examine the narrative that has enabled Rwanda to rebuild towards reconciliation. Rather it is important to recognize again the narrative character of remembering. In the Kigali Memorial Centre stories are told to provoke a narrative in the minds of visitors and a new narrative of hope in the hearts of Rwandans. Writing about Elie Wiesel, a holocaust survivor, Robert McAfee Brown emphasizes the importance of storytelling in creating a bridge between two worlds:

The story teller creates a bridge between two worlds. His story brings us into contact with a world to which access is otherwise denied us. And this is no more than a recapitulation of his own experience, for just as we receive from another so does he. ${ }^{10}$

The Kigali Memorial Centre has become one of many storytellers on behalf of those who can no longer speak for themselves. Their narrative bridges into the hearts of the living and invites a new narrative about resistance, justice and hope.

\footnotetext{
${ }^{9}$ See, for example, Buckley Zistel, S. (2006). Remembering To Forget: Chosen Amnesia As A Strategy For Local Coexistence In Post-Genocide Rwanda, Africa 76,

2.https://muse.jhu.edu/login?auth=0\&type=summary\&url=/journals/africa_the_journal_of_the_international_ african_institute/v076/76.2buckley_zistel.pdf, accessed 22.07.2014

${ }^{10}$ McAfee Brown, R. (1989). Elie Wiesel: Messenger to all humanity. Indiana: University of Notre Dame Press, 44.
} 


\section{Remembering together in Rwanda}

Memorials alone are not sufficient in Rwanda. A devastating history requires more if a resilient, shared narrative is to support non-recurrence and reconciliation. So Rwandans pause to remember together each year in April. Memory runs deep. Pain is great.

In an article in The New Yorker, April 2014, Philip Gourovitch wrote:

President Paul Kagame arrived, along with a dozen other sitting and former heads of state from Africa and Europe. The sky clouded over. The air smelled like rain. A tall man in a brown suit appeared on the stage. He said that he was Fidel, a genocide survivor, and he started to tell how he was supposed to have been killed. Then the screaming began. The first voice was like a gull's, a series of wild, high keening cries; the next was lower and slower, strangled with ache, but growing steadily louder in a drawn-out crescendo; after that came a frantic, full-throated babbling-a cascade of terrible, terrified pleading wails.

Every year, at the genocide-commemoration ceremonies during mourning week, scores of Rwandans erupt in this way, unstrung by grief, convulsed and thrashing when anyone comes near to soothe or subdue them, including, at the stadium, yellow-vested trauma teams who carry them out, bucking and still screaming. You can expect it, but you can't protect against it. All around the stadium, all around the city, all around the country hung misty-gray banners displaying the word kwibuka"remember."11

This year has been more painful than most given that it is the twentieth anniversary of the genocide. Alongside mourning the week focuses on reconciliation and teaching about how genocide happens. Purple is worn and a slogan is adopted for the week, such as, 'it should never happen again.'

Government in partnership with the Church, the most significant group in Rwandan civil society leads remembering for reconciliation. A government department takes responsibility, The National Unity and Reconciliation Commission, which sits under the aegis of Rwanda's Ministry of Justice. The government website describes its purpose:

The policy for unity and reconciliation of Rwandans is a fundamental process for peace and reconciliation in our country. Through raising awareness, conducting research and implementing national programs for unity and reconciliation, National Unity and Reconciliation Commission is striving for a peaceful, united and prosperous nation. ${ }^{12}$

\footnotetext{
${ }^{11}$ Gourevitch, P. "Remembering in Rwanda", The New Yorker, April 212014. http://www.newyorker.com/talk/comment/2014/04/21/140421taco_talk_gourevitch, accessed 22.07.2014.

12 http://www.gov.rw/Justice-Reconciliation, accessed 22.07.2014.
} 
Rwanda's commitment to resist genocide involved remembering together, evoking the narrative of reconciliation together as the people remember the pain and the atrocities of the past. The individual, family and local narratives are set in the broader context of the narrative of a nation's suffering and of a reconciled future.

\section{Remembering where narrative is contested}

Rwanda's commitment to resist genocide involved remembering together under the leadership of political and civil society. There is no such equivalent shared remembering in Northern Ireland. The narrative of what happened over thirty years is the site of wrangling and dispute. Contested narratives of the past result in there being no shared narrative reflecting the diversity of experiences and out of which a future resilient enough to resist what happened in the past happening again is secured. Despite there being no such shared and composite narrative there are a myriad of memorials and acts of remembrance. Crosses mark many roadsides across the country where people died. Communities erect memorials, some in stone and some as murals. Events are held locally to remember those who were lost.

Resolving conflict requires examination of extant narratives of the past and much of this takes place in the re-establishment of the rule of the law so that it can be trusted and become a framework for moral society. Northern Ireland in particular provides an example of contexts in which that rebuilding has been unable, as yet, to stretch across society in a way which enables all to engage in the construction of a new, shared narrative to take society forward. How victims and survivors of the Troubles in Northern Ireland view what happened in the past reveals the disparate understandings and, therefore, the separate and separating remembering that takes place.

In recent months a memorial was placed in a park in Belfast to remember an IRA Volunteer. Thomas Begley was killed while setting a bomb on the Shankill Road in Belfast in 1993. Nine other people were killed and fifty-seven injured. A memorial plaque states that the bomber "died on active service" and is "always remembered by his many comrades and friends."

Representatives of those who were simply shopping on the Shankill Road on a Saturday afternoon in 1993 killed were insulted and appalled by the plaque. While not denying that the Begley family suffered a loss and that their loss is as painful as the loss of anyone else, the families would largely agree that the death of Thomas Begley was different than that of their loved ones. ${ }^{13}$ The dispute about the placing of the plaque uncovers different understandings of what happened in Northern Ireland's past. To Irish Republicans Begley was a volunteer, on active service. For others Begley was a terrorist who did not mind

\footnotetext{
${ }^{13}$ Michelle Williamson, who lost both her parents in the explosion, wrote a personal letter to Begley's parents, asking them to call off the ceremony. She told them she had "no problem in acknowledging your loss" but said the unveiling of the plaque to a bomber was "a sick and cruel insult to the memory of our loved ones". http://www.bbc.co.uk/news/uk-northern-ireland-24599485, accessed 22.07.2014.
} 
making victims. The dispute is about who can rightfully be called a victim and that depends on the narrative of the past. ${ }^{14}$

The situation is complex but this snapshot gives a sense of what it means to live in a context where remembering is fraught with difficulty. As remembering is narrative and not event, disputed and myriad narratives of the past make remembering together problematic.

\section{Remembering as a Day of Private Reflection in Northern Ireland}

The first Day of Private Reflection took place because of the leadership of Healing Through Remembering. The story is instructive in understanding the challenges to remembering together and of evolving a narrative within which everyone can find a place. The Day of Private Reflection takes place on June $21^{\text {st }}$, the longest day of the year. It was impossible to find a day on which no one was killed. It was established as a ground up process and is not agreed or recognized by everyone.

A Day of Reflection was first proposed by Healing Through Remembering, in 2005. A scoping study and consultation were carried out to inform Healing Through Remembering as to the final content of that proposal. The original idea was for a Day of Reflection to serve as:

... a universal gesture of reconciliation, reflection, acknowledgement and recognition of the suffering of so many arising from the conflict in and about Northern Ireland. ${ }^{15}$

The study revealed a broad consensus that there were outstanding unmet needs with regard to how society was responding to the past. Just over half saw the proposal for a Day of Reflection as having potential while the remainder viewed it as inappropriate at this point in Northern Ireland's history. There was also a difference of opinion as to whether or not public events should be an element of the Day. ${ }^{16}$ In light of the findings a staged way forward was proposed ${ }^{17}$ and a discussion process begun. The proposal for discussion was adapted in light of the scoping study from A Day of Reflection to A Day of Private Reflection. ${ }^{18}$ Public dimensions to the Day were omitted in favour of a private reflection. The discussion paper

\footnotetext{
${ }^{14}$ Sinn Féin president Gerry Adams ... told the BBC: "I think we have to be very sensitive about all of this. Thomas Begley has a family, those families arguably are victims." http://www.bbc.co.uk/news/uk-northernireland-24599485, accessed 22.07.2014.

15 "Day of Reflection: A Scoping Study September 2006, Healing Through Remembering", 2. http://www.healingthroughremembering.org/resources/reports, accessed 22.07.2014.

${ }^{16}$ Just under two thirds of participants in the study thought public events would be useful.

17 1. Initiating a debate about a Day of Reflection. 2. Developing core principles. 3. Consultation on the core principles. 4. Planning and implementation. "A Day of Reflection: A Scoping Study September 2006, Healing Through Remembering", 28-32), http://www.healingthroughremembering.org/resources/reports, accessed 22.07.2014.

18 "The paper sets out our proposals for a Day of Private Reflection, which would provide an opportunity for people to reflect individually at home or at work and as a family or a group." "A Day of Private Reflection: Discussion Paper and Proposal September 2006, Healing Through Remembering", 2.

http://www.healingthroughremembering.org/resources/reports, accessed 22.07.2014.
} 
acknowledges that this is precisely because of the difficulties presented by different narratives of the past. The discussion paper notes the difficulties:

We are mindful that the issues around the hurts of the past are difficult, complex, and sensitive and that there is no single solution to addressing the suffering brought about by the conflict in and about Northern Ireland. ${ }^{19}$

Since its inception the Day of Private Reflection has received backing from churches, nongovernmental organisations and others. Some, as in Rwanda, address issues arising from the past and open up discussion about the future. Evaluation of the Day has been provided annually up until 2011 and positive impacts are described in one of those evaluation reports:

Meeting a need and filling the vacuum caused by the absence of any formal process of dealing with the past, and the absence of any other occasion which is neutral, not overtly attached to any other public remembrance, and open to all, including those affected by the conflict in and about Northern Ireland, and those less affected. ${ }^{20}$

The same evaluation report recognizes ongoing division as to whether or not leadership should be given by government. Some believe it should be, although note the need for careful planning among politically mature leaders so that the Day does not get caught in the push and pull of political life.

The explicit role of the Day of Private Reflection remains, therefore, contested beyond providing space for reflection. A question remains as to whether or not remembering together and the consequent narrative that is invoked is more constructive to peace building and reconciliation than separate remembering that, as we have seen, develops separate narratives. These separate narratives, as I have acknowledged, have become the site for wrangling and dispute in Northern Ireland and we are encouraged to consider if, for the sake of the generations to come, a shared or composite narrative can be developed to give resilience to the future.

\section{Remembering the Passover}

The early experience of the community of God's people set the narratives that would bring meaning to the Jewish people down through the generations among them the narrative of the Exodus remembered and reenacted through the Passover Seder and Festival. The Passover Festival begins with the Seder ritual. Families gather to retell the story of how God's people were liberated from slavery in Egypt. The Exodus story is retold on the instruction of Exodus 13:8:

\footnotetext{
19 “A Day of Private Reflection: Discussion Paper and Proposal September 2006, Healing Through Remembering", 2. http://www.healingthroughremembering.org/resources/reports, accessed 22.07.2014 2021 June 2011 “A Day of Reflection Evaluation Report March 2012, Healing Through Remembering”, 2. http://www.healingthroughremembering.org/resources/reports, accessed 22.07.2014.
} 
Then on the seventh day you must explain to your children that you do this because the Lord brought you out of Egypt.

The Exodus narrative is retold as the Haggadic text is read with Passover songs, blessings and commentaries from the Talmud. The story of freedom from slavery is focused on the children who are questioned as part of the ritual, inviting them to see themselves within the context of the slavery to freedom narrative. In this way Jewish children are taught, in their own homes, that remembering is narrative and not event. The Exodus event is recalled but the remembering is of the dynamic nature of movement from slavery to freedom, the cost that was paid and the courage that was shown. The food spread before those gathered at the Seder table further emphasizes the narrative - unleavened bread or matza, bitter herbs, food dipped in salt water, all eaten while reclining. The symbolic nature of the elements to the meal is revealed through the questioning of the children who answer explaining the food is dipped twice as a reminder of the tears of their ancestors, only unleavened bread is eaten because in their hurry to leave their ancestors had no time to let the dough rise, bitter herbs to remind them of the bitterness of slavery and the meal eater reclining, to remind them they are free. The narrative is told in detail and summed up in the declaration of Deuteronomy 26:5-8:

My ancestor was homeless, an Aramean who went to live in Egypt.

There were only a few in his family then, but they became great and powerful, a nation of many people. The Egyptians were cruel and had no pity on us. They mistreated our people and forced us into slavery. We called out for help to you, the Lord God of our ancestors.

You heard our cries; you knew we were in trouble and abused.

Then you terrified the Egyptians with your mighty miracles and rescued us from Egypt. 
The Passover Seder provides the narrative of remembering about how God's people journeyed from slavery to freedom, travelling with one narrative and many characters.

\section{Remembering the Crucifixion}

The Christian Sacrament of the Lord's Supper provides a narrative to remembering that echoes the narrative of the Passover. Sharing bread and wine Christians follow the command of Jesus who, at the celebration of the Passover, shared bread and wine with his disciples. Jesus expressed how he had wanted to celebrate Passover with them for this would be his last and taking bread and breaking it, wine in a cup and blessing it, he shared the instruction that this eating and drinking of bread and wine was to be forever the way of remembering Him.

When the time came for Jesus and the apostles to eat, he said to them, "I have very much wanted to eat this Passover meal with you before I suffer. I tell you that I will not eat another Passover meal until it is finally eaten in God's kingdom." Jesus took a cup of wine in his hands and gave thanks to God. Then he told the apostles, "Take this wine and share it with each other. I tell you that I will not drink any more wine until God's kingdom comes."

Jesus took some bread in his hands and gave thanks for it. He broke the bread and handed it to his apostles. Then he said, "This is my body, which is given for you. Eat this as a way of remembering me!"

After the meal he took another cup of wine in his hands. Then he said, "This is my blood. It is poured out for you, and with it God makes his new agreement. The one who will betray me is here at the table with me! The Son of Man will die in the way that has been decided for him, but it will be terrible for the one who betrays him!" Then the apostles started arguing about who would ever do such a thing. ${ }^{21}$

The ritual of prayer, of lifting up bread and cup, of sharing and responding, of sitting together without discrimination, of rising together to go into the world, provides dramatic representation, as did the Passover Seder, of the faith narrative. The narrative is binding for the community of God's people who are one bread, one body. It is dynamic in its reception as people gather with different burdens and joys, bringing their stories to encounter the narrative of faith. It is also challenging, reminding those who participate that the Table of the Lord is a place from which we rise transformed by an experience of grace which we are charged to take out into the world.

In the Reformed tradition the narrative is set in the context of the narrative of faith from creation to resurrection and anticipation of the coming Kingdom. Traditionally the first prayer recites this history and gives thanks to God for it. The narrative of the Lord's Supper is

\footnotetext{
${ }^{21}$ Luke 22 vv14-23. Contemporary English Version.
} 
further emphasized in the reciting of the $\mathrm{Creed}^{22}$ and the reading of the Words of Institution. Irish Presbyterians receive the bread and wine in their pews, served by the Elders, symbolism of leadership as servanthood. The drama emphasizes the equality of all who have gathered, there is none first to the table and none last to leave. Those who carry decisionmaking authority are reminded that they do so as servants of all and servants of the Lord. When the Supper is ended prayer is offered for the people of the world for whom there is room at the table. Proceedings conclude with a hymn and the final benediction, sending all who have gathered at the table to grace out into the world. The one narrative of the crucifixion has already many stories, from twelve disciples who gathered in the Upper Room to those gathered at the foot of the cross, Jesus' mother among them. Many characters are added to the story as bread and wine is shared across the world and down through the generations.

\section{Remembering as different characters in one narrative}

In these acts of remembering, Passover and Lord's Supper, the memory is of event but the remembering is narrative in both style and experience. Each has a central event to remember, Exodus and Crucifixion, but both share a narrative around the event which is recounting what has gone before and narrating a lifestyle, based in experience, into the future. All, therefore, who share the experience of remembering, begin their own narrative as they leave the Seder Table or the Lord's Table. The new narrative is individual in as much as the experience has been individually appreciated but the new narrative is also communal because the narratives shared bind the gathered community together not only with one another but also with all those who have shared the remembering in the past and will share the same remembering in the future.

A number of important facets of remembering are, therefore, emphasized in the JudeoChristian tradition.

1. Remembering as narrative and not event.

2. Remembering that calls both past and future to mind. The experience of remembering urges participants to their own narrative into the future secured by the narrative of the faith tradition.

3. Remembering is a shared experience among gathered people who connect to others in both past and future and in sharing the narrative the community of faith is bound together even if there are some differing interpretations of that narrative, different experiences and different responses.

\section{Remembering as peacemaking without betrayal}

In post-conflict contexts remembering the impacts of violence are critical in making peace. This is important if the memory of the lost is not to be betrayed. In Northern Ireland there

\footnotetext{
22 In the Presbyterian Church in Ireland some congregations use the Nicene Creed, some the Apostles Creed and some omit the use of a Creed altogether.
} 
are differing and unresolved narratives of the past and to exclude any of them is to invite a sense of betrayal of one's own. If remembering is to contribute to peace it must, therefore, be ethical, effective and inclusive. A narrative of remembering that builds resilience into the future must be shared and composite, focused on narrative more than event and developed at the points where past and future collide. The collision of past and future is at the juncture where there are separate narratives of the past and the here and now. It is at that point that an evolving new narrative begins. The Passover Seder and Lord's Supper give inspiration that this is possible. They also provide the wisdom that one, shared and composite narrative is imperative if peacemaking is to be without betrayal. The Judeo-Christian tradition further challenges remembering to focus on the future as well as the past.

The Judeo-Christian tradition has sometimes failed to recognize the difficulties that arise from individual and group experiences, as noted by Walter Brueggemann:

It is a curious fact that the church has, by and large, continued to sing songs of orientation in a world increasingly experienced as disoriented... It is my judgment that this action of the church is less an evangelical defiance guided by faith, and much more a frightened, numb, denial and deception that does not want to acknowledge or experience the disorientation of life. ${ }^{23}$

The Christian tradition, with its common narrative of the crucifixion, lends a basis to the community on which it can build a future. There may be diversities in understanding but the shared narrative remains as pivotal in drawing together past and future into a pinpoint moment or event and then setting the community off in a new direction from their common narrative of remembering.

The challenge for post-conflict societies is to develop shared narratives of the past, composite in nature, encompassing a broad story that also permits different characters to participate. If the individually different characters are obscured then remembering becomes peacemaking with betrayal and the emerging narrative will have no resilience into the future. Betrayal is likely to store up outrage that will one day manifest itself.

The Lord's Supper takes up the challenge of including the one who facilitated an act of violence against Jesus, Judas Iscariot. In Northern Ireland we face the challenge of how and if to include perpetrators alongside victims. The Passover Seder tells the narrative of a great leader, Moses, who was not to see the Promised Land because of his failings. Both narratives are broad and composite enough to allow individual characters to participate.

\section{Conclusion}

Post-conflict societies face the challenge of remembering those who were lost from among them, each seeking to honour those who lost their lives. At the same time a new society

\footnotetext{
${ }^{23}$ Brueggemann, W. (1984). The Message of the Psalms. Minneapolis: Augsburg Publishing House, 51.
} 
awaits, a society in which former enemies become co-workers in making peace.

Remembering sits at the juncture where the remembered past encounters the potential new society. The juncture is fraught with difficulty; not least feelings of disloyalty to or fear of betraying lost loved ones. These lost loved ones, no matter from what side they came, are most likely to have been killed by those who are now 'co-workers.' When remembering ones own takes precedence over remembering together then each of act of separate remembering tends to work against the possibility of a shared and peaceful society, resilient enough to resist what happened in the past happening again.

To remember together, however, can be experienced as disloyal, making an unnecessary compromise to old enemies. Forgetting differences is not an option. Inclusive remembering must take us beyond our individual or group experience. The future is at stake. Social identity theory explains why we human beings find this difficult:

... individuals identify with social groups in order to increase their self-esteem by comparing their in-group with out-groups along comparison dimensions. ${ }^{24}$

The Northern Ireland experience tells us that learning to remember together is a step-bystep process that maintains the different characters but evolves towards one narrative shared by those different characters. It is a learning yet to be completed. The JudeoChristian tradition supports the work that still needs to be done to complete that process. Remembering takes courage. Remembering together takes even more courage. It is the courage to see one narrative with many different characters. Taking hold of the courage to continue that process could make all the difference in Northern Ireland.

The Revd Lesley Carroll was ordained to the ministry of the Presbyterian Church in Ireland in 1998 and has spent all her working life in North Belfast. The North Belfast community saw more suffering, death and injury than any other area of Northern Ireland. It is a deeply divided community. Lesley works in and between divided communities alongside people from all kinds of backgrounds. She is familiar with the impacts of traumatic experience and with the human desire to build a more peaceful world. As a minister of an urban congregation she works with members of the congregation and wider community to develop projects that respond to the needs of the divided and disenfranchised community in which she lives. Lesley served as a member of the Consultative Group on Dealing with the Past, appointed by the then Secretary of State Peter Hain, which reported to government in 2009. She served as an associate member of the Victims and Survivors Forum 2012-2014 and is appointed by the Minister for Justice to work with anti-peace process dissident Republicans in Maghaberry prison.

\footnotetext{
${ }^{24}$ Niens, U, Cairns, E and Hewstone, M. “Contact and Conflict in Northern Ireland." In Hargie O. and Dickson, D. eds, (2013). Researching the Troubles. Edinburgh: Mainstream Publishing, 124.
} 